\title{
Establishing Climate Change Resilience in the Great Lakes in Response to Flooding
}

\section{Gwendolyn E Gallagher ${ }^{1}$, Ryan K Duncombe², Timothy M Steeves ${ }^{3}$}

1University of Chicago, Department of the Geophysical Sciences, Chicago, IL

${ }^{2}$ University of Chicago, Committee on Immunology, Chicago, IL

${ }^{3}$ University of Chicago, Pritzker School of Molecular Engineering, Chicago, IL http://doi.org/10.38126/JSPG170105

Corresponding Author: gegallagher@uchicago.edu

Keywords: Great Lakes; climate change resilience; EPA; green infrastructure; flooding

\begin{abstract}
Executive Summary
Over the past decade, both the average rainfall and the frequency of high precipitation storm events in the Great Lakes Basin have been steadily increasing as a consequence of climate change. In this same period, cities and communities along the coasts are experiencing record high water levels and severe flooding events (ECC Canada et al. 2018). When cities are unprepared for these floods, the safety of communities and the water quality of the Great Lakes are jeopardized. For example, coastal flooding increases runoff pollution and contaminates the freshwater resource that 40 million people rely on for drinking water (Lyandres and Welch 2012, Roth 2016). Since the Great Lakes are shared between two nations, the United States and Canada, the region is protected by several international treaties and national compacts, including the Great Lakes Water Quality Agreement (GLWQA) and the Great Lakes Restoration Initiative (GLRI). In order to increase climate change resiliency against flooding in the region, we recommend the United States Environmental Protection Agency (EPA) work with Environment and Climate Change Canada to relocate the GLRI under the GLWQA in order to guarantee consistent funding and protection efforts. We additionally recommend expansion of both agreements in their scope and long-term commitments to engender cooperative efforts to protect the Great Lakes against climate change.
\end{abstract}

\section{Statement of issue}

The Great Lakes are an invaluable resource to both the United States (U.S.) and Canada: these five interconnected lakes make up the world's largest freshwater system and contain $21 \%$ of the world's freshwater supply (EPA 2019). Roughly 40 million people in both the U.S. and Canada are dependent on the Great Lakes for clean drinking water (Roth 2016, EPA 2019). Additionally, they are critical to industrial and economic productivity, as $7 \%$ of U.S. and $30 \%$ of Canadian farm production is reliant on the Great Lakes and the regional economy is worth an estimated \$6 trillion (EPA 2019; Desjardins 2017).
As a result of climate change, the Great Lakes Basin has been experiencing more intense and frequent storms that lead to severe flooding events. In 2018, both water levels and precipitation rates were higher than average across the Great Lakes, resulting in flooding in Indiana, Illinois, Michigan, Ontario, and Minnesota (ECC Canada et al. 2018). As demonstrated through these flooding events, the effects of climate change are already impacting communities along the Great Lakes coasts and extreme weather events are predicted to continue increasing in both frequency and intensity (EL and PC 2019). Within the past year, the Great Lakes coasts have experienced several major flooding events: Toronto enforced a shoreline hazard warning throughout the spring (MRCC et al. June 
2019); State of Emergencies from high water, flooding, and wave action were declared in Port Clinton $(\mathrm{OH})$ and all New York counties adjacent to Lake Ontario (MRCC et al. June 2019); and significant shoreline damage was sustained in Traverse City (MI), St. Joseph (MI), Buffalo (NY), Port Colborne (ON), and Chicago (IL). Most notably, Geneva-onthe-Lake (OH) lost $35 \mathrm{ft}$. of shoreline from erosion (ECC Canada et al. 2018; MRCC et al. December 2019; MRCC et al. March 2020).

In addition to jeopardizing coastal infrastructure, major flooding events compromise the Great Lakes' water quality by increasing rates of urban and agricultural runoff. In 1987, forty-three Areas of Concern (AOCs), defined as geographic areas where significant impairment of beneficial use had occurred as a result of human activities at the local level, were identified by an international committee (USGS 2014). Remediation of many of these sites has been completed, but no new sites have been assessed over this period for designation as a Great Lakes AOC. Additionally, there are numerous EPA Superfund sites that may be susceptible to increased flooding risk and discharge toxic, chemical, or nuclear waste into the Great Lakes watershed. Coastal communities and cities along the Great Lakes are currently over-reliant on Combined Sewage Overflows (CSOs), which are a significant source of pollution to the Great Lakes during floods (Lyandres and Welch 2012).

There are 184 CSO-based systems that spill waste into the Great Lakes during flooding events, which are damaging to the ecosystem and water quality (Lyandres and Welch 2012). Unfortunately, funds for infrastructure overhaul are lacking nationwide and revamping of these systems has been delayed repeatedly (EPA 2016). Due to increased risk of lowered water quality from Superfund site and CSO runoff, a new survey identifying AOCs should audit each of these additional at-risk sites with increased flooding frequency and intensity in mind. If steps are not taken to remediate existing AOCs, Superfund sites, and CSOs, the increase in intense flooding events will cause more frequent dumping of hazardous sewage and significant degradation of Great Lakes water quality and wildlife ecosystem.

Increasing climate change resiliency by protecting cities and preventing the pollution of the Great Lakes requires new coastal infrastructure that can withstand recurring, major storm events. While the Great Lakes Basin has only recently begun experiencing higher than average water levels, the eastern and western coastal regions in the U.S. have been actively dealing with the problems of coastal erosion, flooding, and rising sea levels for decades (U.S. Army Corps of Engineers 2015; NOAA Office for Coastal Management 2019; Murphy et al. 2017). Marine coastal regions have begun to acknowledge that, while some man-made infrastructure is necessary to prevent localized flooding and shore erosion, living shorelines and natural, green infrastructure projects are most effective for reducing ecological impacts and enhancing resiliency (Bulleri and Chapman 2010; Glick et al. 2014; Winters et al. 2012; Foster et al. 2011; SuttonGrier et al. 2015). In total, wetlands across the United States are estimated to provide over $\$ 20$ billion worth of storm protection services (Foster et al. 2011).

Green infrastructure and living shorelines are often misunderstood to be feasible exclusively in rural areas along coasts, primarily due to the perceived simplicity of preserving wetlands as opposed to restoring degraded urban coastal ecosystems (Sun and Carson 2020). In reality, green infrastructure along urban coasts is also feasible and more economically advantageous than similar rural measures. Wetlands along urban and metropolitan coasts provide an average of $\$ 2.3$ million/coastal kilometer of protective services annually, as compared to an average of $\$ 126,000 /$ coastal kilometer in rural regions (Sun and Carson 2020; The Office of Rural Health Policy 2018). Though most of the focus has been on marine coasts, green infrastructure and living shorelines have also successfully increased resiliency against floods and major storm events in the Great Lakes region.

For example, a wetland restoration and shoreline stabilization project in Muskegon Lake, MI boosted the local economy by almost $\$ 60$ million (Great Lakes Commission 2018). Rain gardens saved Aurora, IL \$1.8 million, and green roofs and permeable pavement in Chicago, IL capture 85 million gallons of stormwater per year (Glick et al. 2014; Eastern Research Group Inc. 2014). Additionally, a \$200,000 EPA grant for natural infrastructure and flood mitigation in Duluth, $\mathrm{MN}$ is 
forecasted to provide almost $\$ 4.7$ million in benefits for the city (Cassell and Rowan 2014; EPA 2014). Three cost-benefit analyses in the Great Lakes have estimated that green infrastructure could reduce annual damages by $\$ 38,000, \$ 89,000$, and $\$ 2.6$ million in Toledo, Duluth, and Green Bay, respectively (NOAA Office for Coastal Management 2015).

\section{Current Great Lakes policies}

Because the Great Lakes are international waters, the United States and Canada have enacted a series of agreements governing the protection of these lakes as a valuable freshwater resource. Among the most significant of these agreements is the Great Lakes Water Quality Agreement (GLWQA). The GLWQA was enacted in 1978 to set a series of commitments for reducing pollutants and protecting Great Lakes resources (IJC 2012). To achieve water quality goals and standards outlined in the GLWQA, the United States formed the Great Lakes Restoration Initiative (GLRI). The GLRI is an interagency initiative, chaired by the Environmental Protection Agency (EPA) Administrator, to address five major priorities: toxic substances and Areas of Concern, invasive species, nonpoint source pollution, habitats and species, and an accountability, education, and monitoring program (Great Lakes Interagency Task Force 2010).

The GLRI is considered a U.S. bi-partisan success and, although it is mainly an EPA initiative, it is valued by both the American and Canadian governments (Klobuchar et al 2018; Heurtel et al 2017). The GLRI has supported more than 4,700 projects, roughly 5,000 jobs per year, and for every dollar spent through GLRI funding there is an estimated \$3.35 economic benefit for the Great Lakes region (Great Lakes Commission des Grands Lacs 2019; University of Michigan RSQE 2018). As climate change exacerbates flooding events in the region, we recommend increasing funding and expanding the scope of this initiative to enhance the resilience of the natural and manmade systems that millions of people rely on every day.

\section{Recommendations}

\section{i. Recommendation 1: Amend the GLWQA to formally include GLRI}

The GLRI has successfully acquired and invested over $\$ 2.4$ billion in federal and state funding since its launch in 2010. However, the GLRI is only authorized in four-year increments and remains subject to U.S. executive branch volatility and changes in funding priorities from both countries (Interagency Task Force and Regional Working Group Agencies 2019). Because of the success of the GLRI, we recommend its inclusion within the GLWQA so that federal funding from both the U.S. Environmental Protection Agency and Environment and Climate Change Canada is required annually and indefinitely.

An additional benefit of including the GLRI within the GLWQA is that Canadian provincial governments could be included under the initiative given there is not a Canadian equivalent. Bilateral collaboration of this sort has been effective in fisheries management and air quality, where unilateral regulations have been amended to be under the supervision of both U.S. and Canada, bestowing increased resources and regulatory powers (USA and Canada 1990, USA and Canada 1991). Amending the GLWQA to include the GLRI would ensure that both the United States and Canada are financially contributing to water quality efforts and that stable funding will be secured beyond short, four-year increments.

\section{ii. Recommendation 2: Reestablish the GLRI as a Great} Lakes Restoration and Protection Initiative

While the focus on the GLRI is restoration, characteristics of a "restored" Great Lakes are not defined. We recommend that the GLRI is reestablished as the Great Lakes Restoration and Protection Initiative, which acknowledges that maintaining a restored Great Lakes is an ongoing endeavor requiring planning and investments for "post-restoration" infrastructure and maintenance. As shown by the effects of climate change and severe flooding on the Great Lakes' coasts, preventative measures must be taken in building and maintaining green coastal infrastructure. This expansion of the agreement should include a thorough review of climate change predictions and the development of five, ten, twenty-five, and fifty year action plans to 
address the ongoing need for climate change resilience.

iii. Recommendation 3: Include Climate Change Resilience in the GLRI as a 6th Priority

Currently, the five focus areas within the GLRI are: toxic substances and AOCs, invasive species, nonpoint source pollution, habitats and species, and a program for accountability, education, and monitoring (Great Lakes Interagency Task Force 2010). With unprecedented flooding as a result of climate change, we suggest that additional efforts should be made to preserve coastline health and implement green infrastructure in the Great Lakes region. Projects across the United States and the Great Lakes regions have shown that implementation of natural wetlands, permeable pavement, and green shoreline stabilization improve local economies and effectively combat the disastrous effects of flooding. Establishing climate change resilience as a priority in the GLRI expands the reach of the initiative to include the terrestrial Great Lakes basin, therefore enabling the implementation of green infrastructure and reducing the necessity for additional water quality restoration in the future. This addition would not be unprecedented in U.S. policy, as the Department of Defense started implementing climate change impact assessments and resilience

\section{References}

Bulleri, F.; Chapman, M.G. 2010. "The introduction of coastal infrastructure as a driver of change in marine environments". Journal of Applied Ecology. 47 (1): 26-35. https://doi.org/10.1111/j.13652664.2009.01751.x.

Cassell, P.; and Rowan, A. 2014. "Duluth Receives U.S. EPA's First Great Lakes Shoreline Cities Green Infrastructure Grant." EPA Newsroom, February 20, 2014. Accessed April 6, 2020 https://archive.epa.gov/epapages/newsroom a rchive/newsreleases/fab16fb869f3d44d85257c 8500679b91.html.

Desjardins, Jeff. 2017. "If the Great Lakes region were a country, it would have the third largest economy in the world." Business Insider, August 20, 2017. Accessed April 6, 2020. https://www.businessinsider.com/great-lakesregion-economy-infographic-2017-8. recommendations in 2011 (Resetar and Berg, 2016). Climate variability will become more extreme as years go on, so it is important that the next steps taken ensure that the United States and Canada are dedicated to working together to protect one of our greatest natural resources.

\section{Conclusions}

In conclusion, we suggest that the EPA take an active role in advocating for the next step in protecting the Great Lakes ecosystem. We recommend the EPA works with the president, congress, regional states, and Canada to expand the GLWQA to include the GLRI. Acknowledging that the effects of climate change are already being felt in the region and that the future holds more extreme flooding events, we recommend the scope of both the GLWQA and GLRI are expanded to emphasize the impacts of climate change. Furthermore, the timescale of these initiatives should be extended so that action is taken now to address impacts in the decades to come. By adopting these changes, the governing bodies in the Great Lakes Basin can assume responsible stewardship of this invaluable natural resource, boosting resilience of both the natural ecosystem itself, as well as all the communities that rely on the Basin.

Eastern Research Group, Inc. 2014. "Economic Assessment of Green Infrastructure Strategies for Climate Change Adaptation: Pilot Studies in the Great Lakes Region." NOAA Coastal Services Center. Accessed April 6, 2020. https://coast.noaa.gov/data/digitalcoast/pdf/cl imate-change-adaptation-pilot.pdf

Environment and Climate Change Canada and the U.S. National Oceanic and Atmospheric Administration. 2018. "2018 Annual Climate Trends and Impacts Summary for the Great Lakes Basin." https://binational.net/wpcontent/uploads/2019/07/GLISA-2018Climate-Trends-and-Impact-Summary.pdf.

Environmental Law \& Policy Center. 2019. "An Assessment of the Impacts Of Climate Change on the Great Lakes." http://elpc.org/glclimatechange/

EPA. 2019. "Facts and Figures about the Great Lakes." Environmental Protection Agency. Accessed April 6, 2020 www.epa.gov/greatlakes/factsand-figures-about-great-lakes.. 
EPA. 2014. "Great Lakes Shoreline Cities Green Infrastructure Grants." Accessed April 6, 2020. https://www.epa.gov/great-lakesfunding/great-lakes-shoreline-cities-grants.

EPA. 2016. Report to Congress on Combined Sewer Overflows to the Great Lakes Basin. Environmental Protection Agency. www.epa.gov/sites/production/files/201605/documents/gls cso report to congress - 412-2016.pdf.

Great Lakes Interagency Task Force. 2010. Great Lakes Restoration Initiative. FY2010 Report to Congress and the President. Accessed May 30, 2020. https://www.glri.us/sites/default/files/fy2010glri-report-to-congress-201103-38pp.pdf

Foster, J.; Lowe, A.; Winkelman, S. 2011. "The Value of Green Infrastructure for Urban Climate Adaptation. The Center for Clean Air Policy." https://www.cakex.org/sites/default/files/doc uments/The-Value-of-Green-Infrastructure-forUrban-Climate-Adaptation CCAP-Feb-2011.pdf.

Glick, Patty, John Kostyack, James Pittman, Tania Briceno, and Nora Wahlund. 2014. Natural Defenses from Hurricanes and Floods: Protecting America's Communities and Ecosystems in an Era of Extreme Weather. National Wildlife Federation, 2014. Accessed August 19, 2020. https://www.nwf.org/ /media/PDFs/GlobalWarming/2014/Natural-Defenses-FinalEmbargoed-Until-102114-10amET.pdf.

Great Lakes Commission des Grands Lacs. 2019. "Support for Congressional Reauthorization of the Great Lakes Restoration Initiative" October 10, 2019. Accessed $\quad$ August 2020. https://www.glc.org/wpcontent/uploads/FINAL-GLC-Resolution-GLRI20191010.pdf.

Great Lakes Commission, Great Lakes Restoration Initiative, NOAA Office for Coastal Management and Office of Habitat Conservation. 2018. "Restoration Dollars to Bring Six Times Return on Investment." NOAA Office for Coastal Management, 2018. Accessed August 19, 2020. https://coast.noaa.gov/states/stories/restorati on-dollars-bring-six-times-return-oninvestment.html.

Heurtel, David. St-Pierre, Christine. Murray, Glen R. 2017. "Re: Great Lakes Restoration Initiative Funding." Received by Ken Calvert and Betty McCollum, 22 March 2017. Accessed May 30, 2020. http://www.glc.org/wp-content/uploads/GLRIOntario-and-Quebec-Joint-letter-English-March$\underline{\text { 2017.pdf }}$
Klobuchar, A.; Higgins, B.; Slaughter, L.; Duffy, S.; Moore, G.; Kind, R.; Quigley, M. et al. 2018. "Letter to Minister McKenna - Great Lakes Restoration Initiative in Canada." January 4, 2018. Accessed May 30, 2020. https://votesmart.org/publicstatement/1217867/letter-to-ministermckenna-great-lakes-restoration-initiative-incanada\#.Xs8IIxNKjEY

Lyandres, Olga, and Lyman C. Welch. 2012. "Why Investing in Infrastructure Is Critical to Improving Water Quality." Alliance for the Great Lakes, $\quad$ https://greatlakes.org/wpcontent/uploads/2016/08/AGL Reducing CSO 14 FINAL-1.pdf.

Interagency Task Force and Regional Working Group Agencies. 2019. "Great Lakes Restoration Initiative Action Plan III. Fiscal Year 2020 - Fiscal Year 2024." Accessed May 30, 2020. https://www.epa.gov/sites/production/files/2 019-10/documents/glri-action-plan-3-20191030pp.pdf.

IJC. 2012. "Great Lakes Water Quality Agreement." Conclusion date: September 7, 2012. International Joint Commission. Accessed April 15 , 2020.

https://www.ijc.org/sites/default/files/201807/GLWQA 2012.pdf

Murphy, A. et al. 2017. Washington State Coast Resilience Assessment Final Report. William D. Ruckelshaus Center. Accessed August 19, 2020. http://mrsc.org/getmedia/0498ef44-89e846c7-b834-469b992196c6/Washington-CoastResilience-Assessment-Report.aspx.

NOAA Regional Climate Services Program. 2019. Quarterly Climate Impacts and Outlook: December 2019. NOAA. Accessed August 19, 2020. V

NOAA Regional Climate Services Program. 2019. Quarterly Climate Impacts and Outlook: June 2019. NOAA. Accessed August 19, 2020. https://binational.net/wpcontent/uploads/2019/07/GL_Spring2019_Fina $\underline{\text { l.pdf }}$

NOAA Regional Climate Services Program. 2020. Quarterly Climate Impacts and Outlook: March 2020. NOAA. Accessed August 19, 2020. https://binational.net/wpcontent/uploads/2020/03/GL Winter2020 Fin al.pdf.

NOAA Office for Coastal Management. 2015. A Guide to Assessing Green Infrastructure Costs and Benefits for Flood Reduction. NOAA, 2015. Accessed August 19, 2020. http://greatlakesresilience.org/sites/default/fil es/gi-cost-benefit.pdf. 
NOAA Office for Coastal Management. 2019. Coastal Community Resilience Indicators and Rating Systems. NOAA, 2019. Accessed August 19, 2020. https://coast.noaa.gov/data/digitalcoast/pdf/re silience-indicators.pdf.

The Office of Rural Health Policy. 2018. List of Rural Counties And Designated Eligible Census Tracts in Metropolitan Counties. Office of Rural Health Policy, 2018. Accessed August 19, 2020. https://www.hrsa.gov/sites/default/files/hrsa/ ruralhealth/resources/forhpeligibleareas.pdf.

Resetar, Susan and Neil Berg. 2016. An Initial Look at DoD's Activities Toward Climate Change Resiliency. RAND Project AIR FORCE, 2016. Accessed August 19, 2020. https://www.rand.org/content/dam/rand/pub s/working papers/WR1100/WR1140/RAND W R1140.pdf.

Roth, Amanda. 2016. "The Fight Over Who Gets Clean Drinking Water From the Great Lakes." Vice, April 22,

2016. https://www.vice.com/en us/article/ezpp4z/th e-fight-over-who-gets-clean-drinking-waterfrom-the-great-lakes-Michigan-Ontario.

Sun, Fanglin and Richard Carson. 2020. "Coastal wetlands reduce property damage during tropical cyclones". Proceedings of the National Academy of Sciences. 117 (11): 5719-5725. http://doi.org/10.1073/pnas.1915169117.

Sutton-Grier, Ariana, Kateryna Wowk and Holly Bamford. 2015. "Future of our coasts: The potential for natural and hybrid infrastructure to enhance the resilience of our coastal communities, economies and ecosystems". August 1, 2015. Environmental Science \& Policy. 51: 137-148. http://doi.org/10.1016/j.envsci.2015.04.006.
United States and Canada. 1991. "Agreement Between the Government of Canada and the Government of the United States of America on Air Quality." Conclusion date: 13 March, 1991. https://www.canada.ca/content/dam/eccc/mig ration/main/air/1e841873-e03b-4f16-a8e1eb2e37095b62/canadausairqualityagreement.p df.

United States and Canada. 1990. "Agreement on Fisheries Enforcement". Conclusion date: September 26, 1990. http://extwprlegs1.fao.org/docs/pdf/can5111. pdf.

University of Michigan Research Seminar in Quantitative Economics. 2018. Socioeconomic Impacts of the Great Lakes Restoration Initiative. University of Michigan. Accessed May 30, 2020. http://www.calumetcollaborative.org/uploads/ 1/0/0/2/100279892/socioeconomic impacts o f the great lakes restoration initiative.pdf.

U.S. Army Corps of Engineers. 2015. North Atlantic Coast Comprehensive Study: Resilient Adaptation to Increasing Risk Main Report. U.S. Army Corps of Engineers. Accessed August 19, 2020. https://www.nad.usace.army.mil/Portals/40/d ocs/NACCS/NACCS main report.pdf.

U.S. Geological Survey. 2014. Monitoring of Wild Fish Health at Selected Sites in the Great Lakes Basin: Methods and Preliminary Results. U.S. Department of the Interior. Accessed April 15, 2020. https://pubs.usgs.gov/of/2014/1027/pdf/of20 14-1027.pdf

Winters, Paul, Corey Piasecki, and Robert Pirani. 2012. 9 Ways to Make Green Infrastructure Work. Regional Plan Association, 2012. Accessed August 19, 2020. https://rpa.org/uploads/pdfs/RPA-9-Ways-toMake-Green-Infrastructure-Work.pdf .

Gwendolyn Gallagher is a PhD candidate in Geophysical Sciences at the University of Chicago studying marine microbes in the context of the global carbon cycle. She is interested in the intersection of environmental research, climate justice, and public policy.

Ryan Duncombe is a PhD candidate in Immunology at the University of Chicago. He studies the biochemical mechanisms of anti-inflammatory immune responses. He is interested in environmental biochemistry and public policy.

Timothy Steeves recently received his PhD from University of Chicago's molecular engineering program, where he studied catalysts for solar fuel conversion. His interest in environmental policy and sustainable energy production led him to science policy as a career interest and to found the UChicago Science Policy Group.

Disclaimer - The opinions and statements expressed belong to the authors and do not represent the views of the institutions with which they are affiliated 